\title{
Performance of a Refrigeration Absorption Cycle Driven by Different Power Sources
}

\author{
Sameh Alsaqoor ${ }^{1}$, Khaled S. AlQdah ${ }^{2 *}$ \\ ${ }^{1}$ Mechanical Engineering Department, Tafila Technical University, Tafila, Jordan \\ ${ }^{2}$ Mechanical Engineering Department, Faculty of Engineering, Taibah University, Medina, KSA \\ Email: sameh@wp.pl, ${ }^{*}$ dr.khaled qdah@yahoo.com
}

Received 25 April 2014; revised 27 May 2014; accepted 8 June 2014

Copyright @ 2014 by authors and Scientific Research Publishing Inc.

This work is licensed under the Creative Commons Attribution International License (CC BY).

http://creativecommons.org/licenses/by/4.0/

(c) () Op Open Access

\section{Abstract}

In this study, performance assessment of absorption refrigeration cycle has been carried out under variable power sources namely electric, conventional fuel and renewable energy sources. The ammonia-water absorption cycle was used in this work, the temperatures at each point in the cycle such as generator, absorber, evaporator and condenser have been measured and with using absorption device system. The coefficient of performance and efficiency of the plant were measured and then compared. The results showed that when the cycle driven by electricity, the coefficient of performance varied 0.694 to 1.032 along the test time and the generator temperature changes from $48.1^{\circ} \mathrm{C}$ to $101.5^{\circ} \mathrm{C}$ with the average efficiency of $57.1 \%$ and average coefficient of performance of 0.78 . When methane used as a fuel to generate power the coefficient of performance varied between 0.686 and 0.94 under the generator temperature of $123.3^{\circ} \mathrm{C}$ and $127.4^{\circ} \mathrm{C}$ and average efficiency of $\mathbf{4 0 . 0 2 \%}$ with coefficient of performance of 0.735 . Solar energy used as the alternative source of power which is the clean and safe power source and when the plant driven by the solar thermal energy, the coefficient of performance reached to 0.801 under the generator temperature of $91^{\circ} \mathrm{C}$, but the system efficiency about $11.68 \%$ along the test time. Solar energy can be used efficiently and replaced the conventional power sources to drive the absorption refrigeration unit.

\section{Keywords}

Absorption, Solar Energy, Performance, Generator, COP

\section{Introduction}

Many people in the world are currently experiencing dramatic shifts in lifestyle as their economies make the 
transition from subsistence to an industrial or service base. The largest increases in energy demand will take place in developing countries where the proportion of global energy consumption is expected to increase from 46 to 58 percent between 2004 and 2030 [1]. Energy consumption in developing countries is projected to grow at an average annual rate of 3 percent from 2004 to 2020. Energy consumption in developing regions is projected to surpass that in industrialized regions and about half of the increase in global energy demand by 2030 will be for power generation and one fifth for transport needs-mostly in the form of petroleum-based fuels (EIA, 2007).

Conventional air-conditioning systems require high quality energy, electricity, generated from primary energy resources, however, in spite of CFC-free cooling liquids, and energy consumption and pollution level surprising. Therefore, from ecological point of view needs to be implemented as the green house gases effect remains threat to the fact, most of the buildings' cooling demands in summer are associated with high solar energy availability, which offers an opportunity to further exploit solar energy for cooling. Solar cooling technology provides an important contribution to both economical and ecological energy supply. Thermally driven refrigeration systems are providing golden energy by using heat as motive energy. This heat can be obtained from combined heat and power systems, waste-heat sources or solar en energy. Since Jordan in a none oil producing country and the energy issues and the seek for new alternative energy sources one of the most priority for us, therefore we will focus on the alternative energy sources to operate the absorption refrigeration cycle that may be used for cooling and refrigeration processes. Solar cooling and absorption cooling system has been witnessed a lot of development and studies by researcher in the world and the almost available studies are:

Hattem and Dato (1983) [2] described of an active solar cooling system, using a $\mathrm{LiBr}-\mathrm{H}_{2} \mathrm{O}$ absorption machine. Bong et al. (1987) [3] studied the performance a solar powered air conditioning system. Yeung et al. (1992) [4] investigated the performance of a solar powered air conditioning system in Hong Kong. Chinnappa et al. (1993) [5] investigated the solar-assisted vapor compression/absorption cascaded air-conditioning systems. Best and Ortega (1999) [6] studied the solar cooling and refrigeration. Chen and Hihara (1999) [7], a new absorption refrigeration cycle using solar energy has been carried out. Deng and Ma (1999) [8] conducted an experimental studies on the characteristics of an absorber using $\mathrm{LiBr} / \mathrm{H}_{2} \mathrm{O}$ solution as working fluid. $\mathrm{Li}$, Z . and Sumathy (2000) [9] reviewed the technology development in the solar absorption air-conditioning systems. Rivera and Xicale (2001) [10] studied the heat transfer Coefficients in two-phase flow for the water/lithium bromide mixture used in solar absorption refrigeration systems. Grossman (2002) [11] conducted an experimental study of solar powered systems for cooling, dehumidification and air conditioning. Lokurlu and Müller (2005) [12] built the first solar cooling system based on trough collectors combined with double effect absorption chillers. Syed et al. (2005) [13] carried out an experimental investigation of a solar cooling system in Madrid. Balaras et al. (2007) [14] cited a total of 54 solar air-conditioning projects in Europe are inoperation, 33 of them are working with lithium bromide-water absorption chillers. Kim (2007) [15] conducted a theoretical study on solar absorption cooling in Delft University of Technology, Netherlands. Zambrano et al. (2007) [16] developed a new model and validation of a solar cooling plant. Khaled AlQdah (2011) [17] conducted an experimental study to evaluate the performance of aqua ammonia auto air conditioner system using exhaust waste energy.

In recent years, many researchers have been carried out on refrigeration systems driven by solar energy, which achieves conservation of conventional energy and a reduction of environmental pollution. Although many kinds of refrigeration systems have been developed and studied. It can be seen that very little work has been done to compare the performance of refrigeration or air conditioning system under different power sources which is the motivation of our work that will compare the performance of absorption refrigeration under different climatic conditions in Jordan. The structure of this manuscript starts by discussing the related research from the body of literature in Section one, while Section two presents a description of absorption cycle. Section three displayed experimental apparatus and setup. While the experimental methodology was presented in Section four. The results were presented and discussed in section five. Finally; section six summarized the study findings through the conclusion.

\section{Absorption Cycle}

The absorption cycle is a process by which refrigeration effect is produced through the use of two fluids and some quantity of heat input, rather than electrical input as in the more familiar vapor compression cycle [18]. Both vapor compression and absorption refrigeration cycles accomplish the removal of heat through the evapo- 
ration of a refrigerant at a low pressure and the rejection of heat through the condensation of the refrigerant at a higher pressure. In the absorption system, a secondary fluid or absorbent is used to circulate the refrigerant. As the name implies, absorption refrigeration systems involve the absorption of a refrigerant by a transport medium. The most widely used absorption refrigeration system is the ammonia-water system shown in Figure 1, where ammonia $\left(\mathrm{NH}_{3}\right)$ serves as the refrigerant and water $\left(\mathrm{H}_{2} \mathrm{O}\right)$ as the transport medium. Absorption machines are commercially available today in two basic configurations. For applications above $32^{\circ} \mathrm{F}$ (primarily air conditioning), the cycle uses lithium bromide as the absorbent and water as the refrigerant. For applications below $32^{\circ} \mathrm{F}$, an ammonia/water cycle is employed with ammonia as the refrigerant and water as the absorbent.

\section{Experimental Setup and System Description}

A series of experiments were carried out in Tafila Technical University mechanical engineering laboratories using absorption ammonia - water cycle device as depicted in Figure 2. The system is similar to vapor-compression system, except that the compressor has been replaced by a complex absorption mechanism consisting of an absorber, a generator, a control valve, and a rectifier. Once the pressure of $\mathrm{NH}_{3}$ is raised by the previous components, it is cooled and condensed in the condenser by rejecting heat to the surroundings, is throttled to the evaporator pressure, and absorbs heat from the refrigerated space as it flows through the evaporator.

The heat on the generator (Boiler) transferred to the ammonia vapor and the result is driven it from the solution. This hot vapor rises into the rectifier and a portion of the water condenses and flows by gravity into the absorber. The hot ammonia vapor continues to rise into the condenser where it gives up its heat to the surrounding air and condenses into a liquid. The liquid ammonia enters by gravity into the evaporator, where it is mixed with hydrogen gas. Circulation of hydrogen gas causes a reduction in pressure within the evaporator. The low pressure causes the ammonia liquid to boil into a gas (evaporating) and absorbing heat in the process (refrigerating effect).

The mixture of hydrogen/ammonia vapor that's carrying the absorbed heat is now drawn by gravity into the absorber. Because the water from the separator has a greater affinity for ammonia, it separates from the hydrogen gas. The hydrogen gas being very light rises and returns to the generator to start the cycle again.

\section{Methodology}

The system was prepared to test by three different types of energy sources as follows and as shown in Figure 3.

1. Wired layouts:

I. In the case of electrical energy, the plug connected to power network and switched the electric heater which enfolds the generator.

II. When the system heated by LPG gas, the combustion take place in the generator, then the heat transferred to solution by surface of combustion chambers.

III. The apparatus driven by thermal solar energy; at the help of tube connected it with the output of solar flat plate collector. The all systems collectors (with an angle $45^{\circ}$ tracked in the sun direction) and absorber refrigeration located in open space at Tafila Technical University.

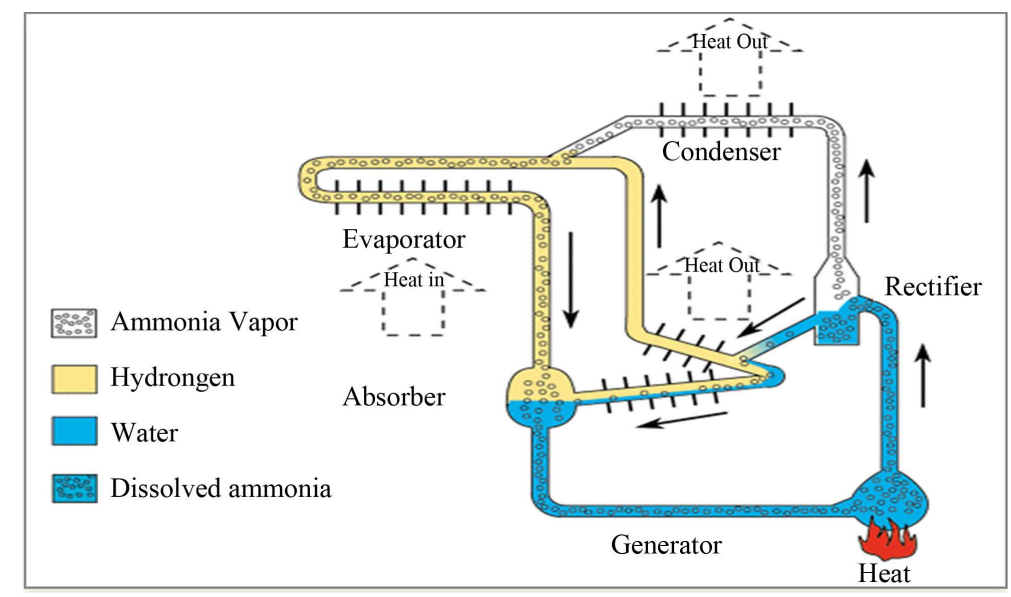

Figure 1. Absorption cycle schematic diagram. 


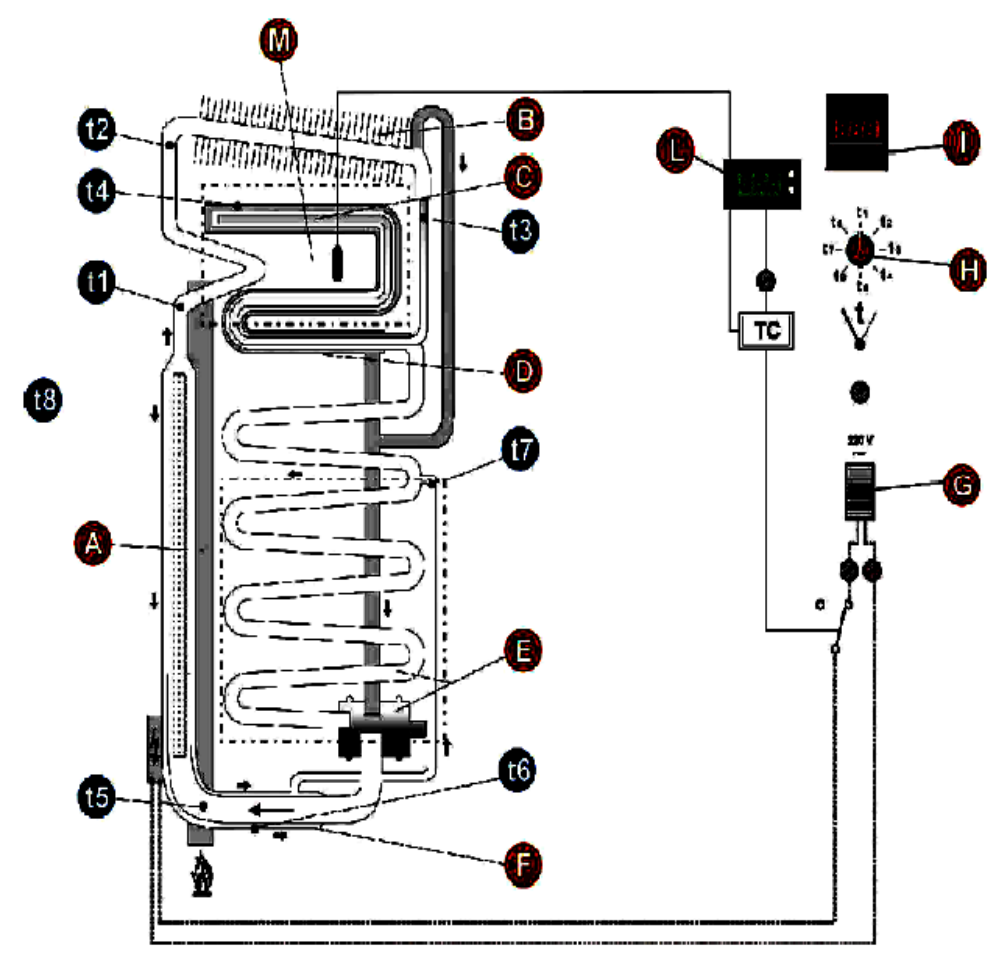

Figure 2. Absorption ammonia-water cycle device.
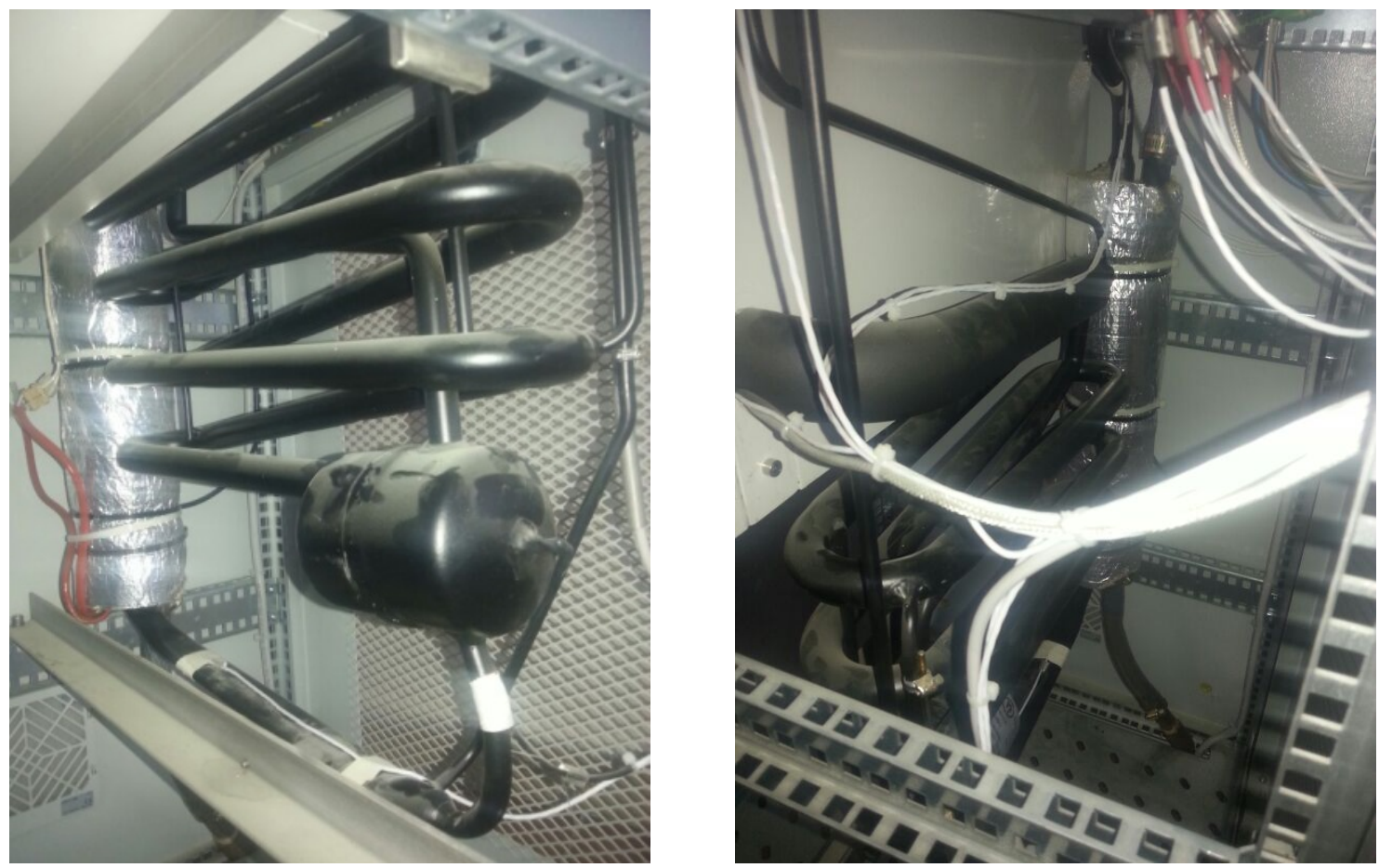

Figure 3. The absorption refrigeration cycle tested for different kinds of energy.

2. For each, and for all those cases, the measurement takes every 15 minutes, until the system obtaining the steady state conditions.

3. The results were compiled and presented in the form of figures.

The equations used for developed the measuring results covering plant efficiency, absolute coefficient of per- 
formance and real coefficient of performance can be represented as follows:

Absolute coefficient of performance (theoretical)

$$
\operatorname{COP}_{a b s}=\frac{T_{G}-T_{A}}{T_{G}} \times \frac{T_{E}}{T_{C}-T_{E}} \quad[19]
$$

where:

$T_{G}$ : Temperature of the generator $\left[{ }^{\circ} \mathrm{C}\right]$

$T_{A}$ : Temperature of the absorber $\left[{ }^{\circ} \mathrm{C}\right]$

$T_{E}$ : Temperature of the evaporator $\left[{ }^{\circ} \mathrm{C}\right]$

$T_{C}$ : Temperature of the condenser $\left[{ }^{\circ} \mathrm{C}\right]$

Real coefficient of performance (experimentally)

$$
\mathrm{COP}_{R}=\frac{\text { Heat removed }}{\text { Energy consumed }}=\frac{Q_{c}}{E} \quad[19]
$$

where:

$Q_{C}$ : Heat removed from cold room $[\mathrm{kJ}]$

$E$ : Energy consumed $[\mathrm{kJ}]$

Heat removed from cold room

$$
Q_{c}=V_{C R} \times \rho_{\text {air }} \times C_{P_{\text {air }}} \times\left(T_{\text {amb. }}-T_{C R}\right)
$$

where:

$V_{C R}$ : Volume of the room $\left[\mathrm{m}^{3}\right]$

$\rho_{\text {air }}$ : Density of air $=1,3\left[\mathrm{~kg} / \mathrm{m}^{3}\right]$

$C_{P_{\text {air }}}$ : Specific heat of air $=0.25\left[\mathrm{Kcal} / \mathrm{kg} \cdot{ }^{\circ} \mathrm{C}\right]$.

$T_{a m b}$ : Ambient temperature [ $\left.{ }^{\circ} \mathrm{C}\right]$

$T_{C R}$ : Cold room temperature [ $\left.{ }^{\circ} \mathrm{C}\right]$

The efficiency of the absorption refrigeration cycle can be calculated as:

$$
\eta=\frac{C O P_{R}}{C O P_{a b s}}
$$

\section{Results and Discussion}

The absorption refrigeration system was used to test and compare the suitability of different sources of energy and their impact on working conditions at the absorption refrigeration process. So it has been used three types of energy sources: Electrical energy (coil), LPG gases and solar energy with the help of flat plate solar collector at Tafila Technical University in Jordan. The variation of temperature changes in the generator have been represented in Figure 4 for all sources of energy. After 15 minutes of operation of the system, the temperature increases for a gas fuel to the value of $1230^{\circ} \mathrm{C}$ in the same time and the temperature ranged around $500^{\circ} \mathrm{C}$ for the other sources. After 30 minutes of operation the variation of temperature in the generator minimized and to the end of the measurements remained at the level of $1300^{\circ} \mathrm{C}$ for gas fuel and $1000^{\circ} \mathrm{C}$ for electrical energy, while in the case of solar energy the temperature is changed all the time and only at the end measurements equalized taken value about $800^{\circ} \mathrm{C}$.

When it comes to the changes of temperature in an evaporator they have been represented in Figure 5 . The temperature practically decreases linearly, when electrical energy is used to run the system, getting on the end of the experiment values $-20^{\circ} \mathrm{C}$. The temperature on the evaporator decreases to about $-30^{\circ} \mathrm{C}$ when LPG fuel used to run the absorption refrigeration system, but in the case of the solar energy is used to run the system, the temperature has received at the level of $70^{\circ} \mathrm{C}$.

Figure 6 shows the important value, it means Coefficient of Performance. It can be seen in the case of the $\mathrm{COP}_{\text {abs }}$ (Theoretical COP) which is calculated only on the basis of the measured temperature at various points in the system, as temperature on the generator, temperature on the absorber, temperature on the evaporator and temperature on the condenser almost all equal and varies between 0.69 to 0.8 for all kinds of sources of energy. While the situation is somewhat different in the case of value of real coefficient of performance (COPR), the differences is great, especially when used electrical energy (The COP reached about 0.46 ) to run the system and 


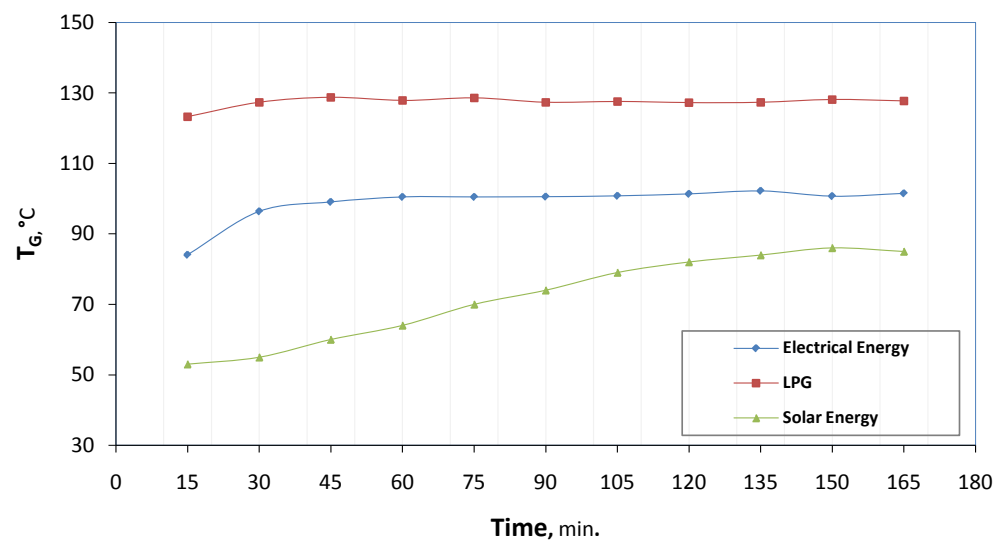

Figure 4. The changing of temperature at the generator of an absorption refrigeration cycle.

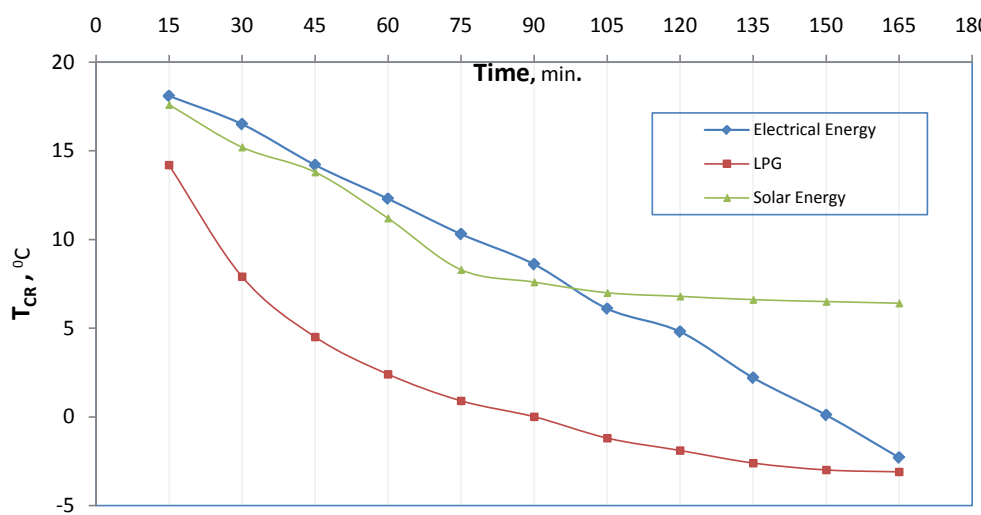

Figure 5. The changing of temperature at the evaporator (cooling room) of an absorption refrigeration cycle.

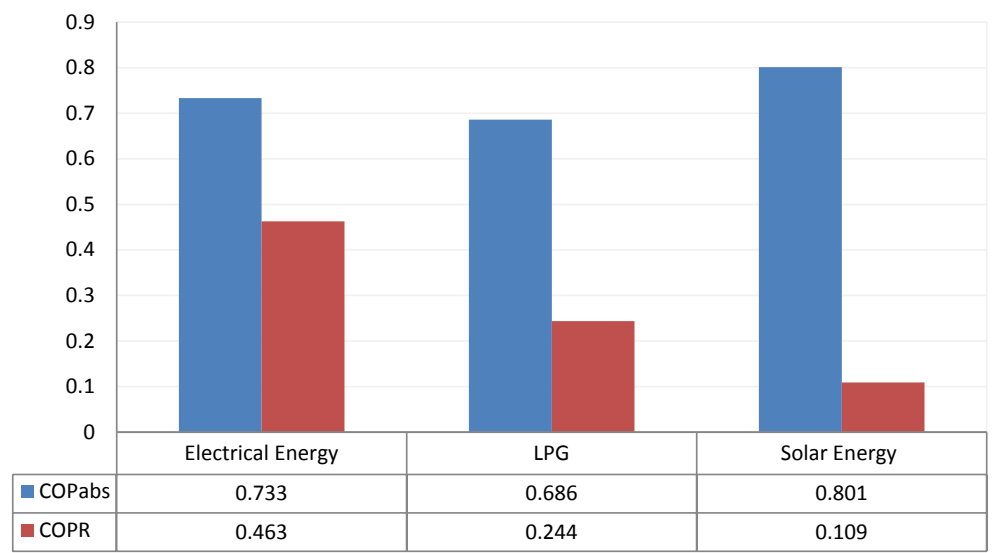

Figure 6. The coefficient of performance for many types of energy runs the absorption refrigeration system.

solar energy ,the COPR about 0.10 whereas the COPR equal about 0.24 .

From the Figure 7, it's evident that the maximum efficiency can be reached for an absorption refrigeration system runs by electrical energy achieved value of $63 \%$, whereas receives on the level of $45 \%$ for the system runs by LPG gases, so the efficiency dramatically reduced for the absorption refrigeration system powered by flat plate solar collector. 


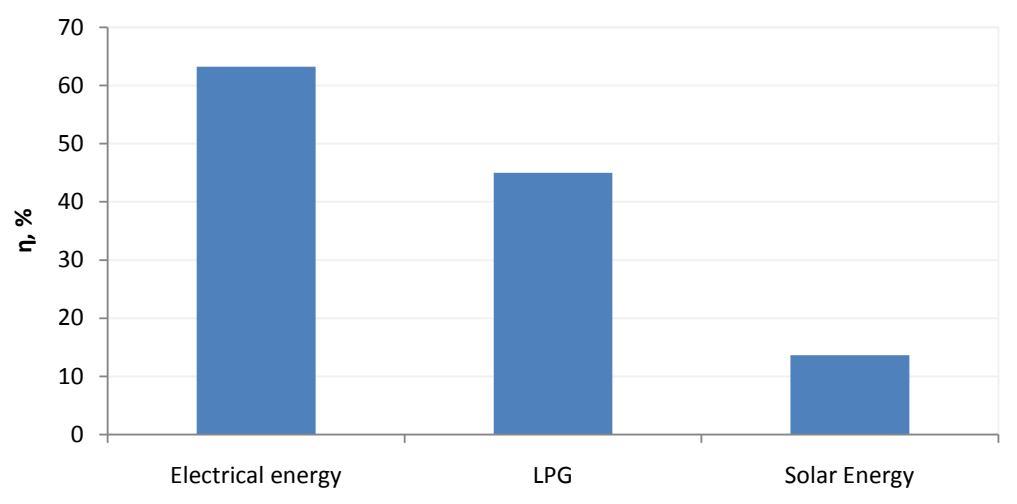

Figure 7. The efficiency of an absorption refrigeration cycle runs by many types of energy sources.

Even the fact that the solar energy has the lowest performance but has a lot of advantages, among others, it is free sources and does not affect the degradation of the environment, also in desert areas where there is no power grid, can be wins big role and application in refrigeration and air conditioning division.

Finally, it can be say that the $\mathrm{COP}_{\text {abs }}$, depends on the temperature at various points in the system, for example, the flat plate solar collector cannot assure high temperatures in the generator which is one of the important components of the system and serious influence at the performance. Also consumed energy [E, kJ] losses for encounters various sources such as these losses are smaller in the case of electricity the coil is directly in the generator, in the case of solar energy the losses in the pipes connected two systems, it is the fact that the $\mathrm{COP}_{\mathrm{abs}}$ is larger for solar energy source system.

\section{Conclusion}

The possibility of having a refrigeration system driven by the solar energy is a huge advantage in Jordan (as well as other parts of the world). There are many circumstances where people do not have access to electricity or gas to power a refrigeration system. An absorption refrigeration cycle employing an ammonia-water solution as the working fluid has been investigated in this work. The cycle has been powered by three different power sources to providing a high temperature heat source for absorption cooling unit. Based on the results of the investigations performed in this study, the concluding remarks are as follows: the renewable energy resources like solar energy can contribute effectively to the supply of heat to the refrigeration load. The efficiency of absorption cooling based on a type resource of heat reliant on the temperature to be formed inside the generator, this temperature using to dominate the efficiency and coefficient of performance COP. for absorption refrigeration system. For this we find the best of efficiency and COP was found when using the electricity as a power source for the absorption cycle, after that using of methane instead of electricity but with its environmental impact and pollution. The clean and safe power source when we using solar thermal energy in spite of lower COP and efficiency. A number of equipment requirements and limitations must be considered in the analysis and design of powered absorption systems.

The first limitation deals with the problem of reduced efficiency of the absorption cooler under start-up and transient conditions. Typical absorption coolers do not reach operating efficiency until after an hour or more of operation time, machine which is cycled on and off regularly will have a drastically reduced average coefficient of performance when compared to a machine in steady state performance, this problem has been overcome in at least one installation by the use of a cold storage unit. The second limitation is the high cost; which is attributable to the use of some additional equipment for the absorption cooling such as absorber and boiler. Research is under way to develop and cooling units at relatively low cost through a number of different factors may contribute to this subject.

\section{References}

[1] Ministry of Energy and Mineral Resources, Jordan (2011) Annual Report. Amman.

[2] Hattem, D.V. and Dato, P.A. (1981) Description of an Active Solar Cooling System, Using a LiBr- $\mathrm{H}_{2} \mathrm{O}$ Absorption 
Machine. Energy and Buildings, 3, 169-196.

[3] Bong, T.Y., Ng, K.C. and Tay, A.O. (1987) Performance Study of a Solar Powered Air Conditioning System. Solar Energy, 39, 173-182. http://dx.doi.org/10.1016/S0038-092X(87)80025-7

[4] Yeung, M.R., Yuen, P.K., Dunn, A. and Cornish, L.S. (1992) Performance of a Solar Powered Air Conditioning System Hong Kong. Solar Energy, 48, 309-319. http://dx.doi.org/10.1016/0038-092X(92)90059-J

[5] Chinnappa, J.C., Crees, M.R., Murthy, S.S. and Srinivasan, K. (1993) Solar-Assisted Vapor Compression/Absorption Cascaded Air-Conditioning Systems. Solar Energy, 50, 453-458. http://dx.doi.org/10.1016/0038-092X(93)90068-Y

[6] Best, R. and Ortega, N. (1999) Solar Refrigeration and Cooling. Renewable Energy, 16, 685-690. http://dx.doi.org/10.1016/S0960-1481(98)00252-3

[7] Chen, G.M. and Hihara, E. (1999) Anew Absorption Refrigeration Cycle Using Solar Energy. Solar Energy, 66, 479482. http://dx.doi.org/10.1016/S0038-092X(99)00042-0

[8] Deng, S.M. and Ma, W.B. (1999) Experimental Studies on the Characteristics of an Absorber Using $\mathrm{LiBr} / \mathrm{H}_{2} \mathrm{O} \mathrm{Solution}$ as Working Fluid. International Journal of Refrigeration, 22, 293-301. http://dx.doi.org/10.1016/S0140-7007(98)00067-X

[9] Li, Z.F. and Sumathy, K. (2000) Technology Development in the Solar Absorption Air-Conditioning Systems. Renewable Sustainable Energy Reviews, 4, 267-293. http://dx.doi.org/10.1016/S1364-0321(99)00016-7

[10] Rivera, W. and Xicale, A. (2001) Heat Transfer Coefficients in Two Phase Flow for the Water/Lithium Bromide Mixture Used in Solar Absorption Refrigeration Systems. Solar Energy Materials and Solar Cells, 70, 309-320.

[11] Grossman, G. (2002) Solar Powered Systems for Cooling, Dehumidification, and Air Conditioning. Solar Energy, 72, 53-62. http://dx.doi.org/10.1016/S0038-092X(01)00090-1

[12] Lokurlu, A. and Müller, G. (2005) Experiences with the World Wide First Solar Cooling System Based on Trough Collectors Combined with Double Effect Absorption Chillers. Proceedings of the International Conference on Solar Air-Conditioning, Bad Staffelstein.

[13] Syed, A., Izquierdo, M., Rodriguez, P., Maidment, G., Missenden, J., Lecuona, A. and Tozer, R. (2005) Anovel Experimental Investigation of a Solar Cooling System in Madrid. International Journal of Refrigeration, 28, 859-871. http://dx.doi.org/10.1016/j.ijrefrig.2005.01.007

[14] Balaras, C.A., Grossman, G., Henning, H.M., Ferreira, C.A.I., Podesser, E., Wang, L. and Wiemken, E. (2007) Solar Air Conditioning in Europe-An Overview. Renewable and Sustainable Energy Reviews, 11, 299-314. http://dx.doi.org/10.1016/j.rser.2005.02.003

[15] Kim, D.-S. (2007) Solar Absorption Cooling. Ph.D. Dissertation, Delft University of Technology, Delft.

[16] Zambrano, D., Bordons, C., Garcia-Gabin, W. and Camacho, E.F. (2008) Model Development and Validation of a Solar Cooling Plant. International Journal of Refrigeration, 31-32, 315-327.

[17] AlQdah, K.S. (2011) Performance and Evaluation of Aqua Ammonia Auto Air Conditioner System Using Exhaust Waste Energy. Energy Procedia, 6, 467-476. http://dx.doi.org/10.1016/j.egypro.2011.05.054

[18] Didacta Italia (2011) T108/6D, Educational Equipment on the Absorption Refrigeration Cycle User’s Manual and Exercise Guide.

[19] Cengel, Y. and Boles, M. (2010) Thermodynamics: An Engineering Approach. 7th Edition, McGraw-Hill, New York. 


\section{Nomenclature}

COP: Coefficient of performance

$C p_{\text {air }}$ : Specific heat for air

$E$ : Energy consumed

${ }_{G} W_{A}$ : The work done between the generator and absorber

${ }_{C} W_{E}$ : The work done between the condenser and evaporator

$Q_{G}$ : The heat removed from the generator

$Q_{E}$ : The heat removed from the generator

$P_{E}$ : The electric power of the generator [KW]

$T_{G}$ : Temperature of the generator

$T_{A}$ : Temperature of the absorber

$T_{E}$ : Temperature of the evaporator

$T_{C}$ : Temperature of the condense

$T_{a m b}$ : Room temperature $\left[{ }^{\circ} \mathrm{C}\right]$

$\Delta h=$ Change of enthalpy

$\rho$ : Density

$\eta$ : Efficiency 
Scientific Research Publishing (SCIRP) is one of the largest Open Access journal publishers. It is currently publishing more than 200 open access, online, peer-reviewed journals covering a wide range of academic disciplines. SCIRP serves the worldwide academic communities and contributes to the progress and application of science with its publication.

Other selected journals from SCIRP are listed as below. Submit your manuscript to us via either submit@scirp.org or Online Submission Portal.
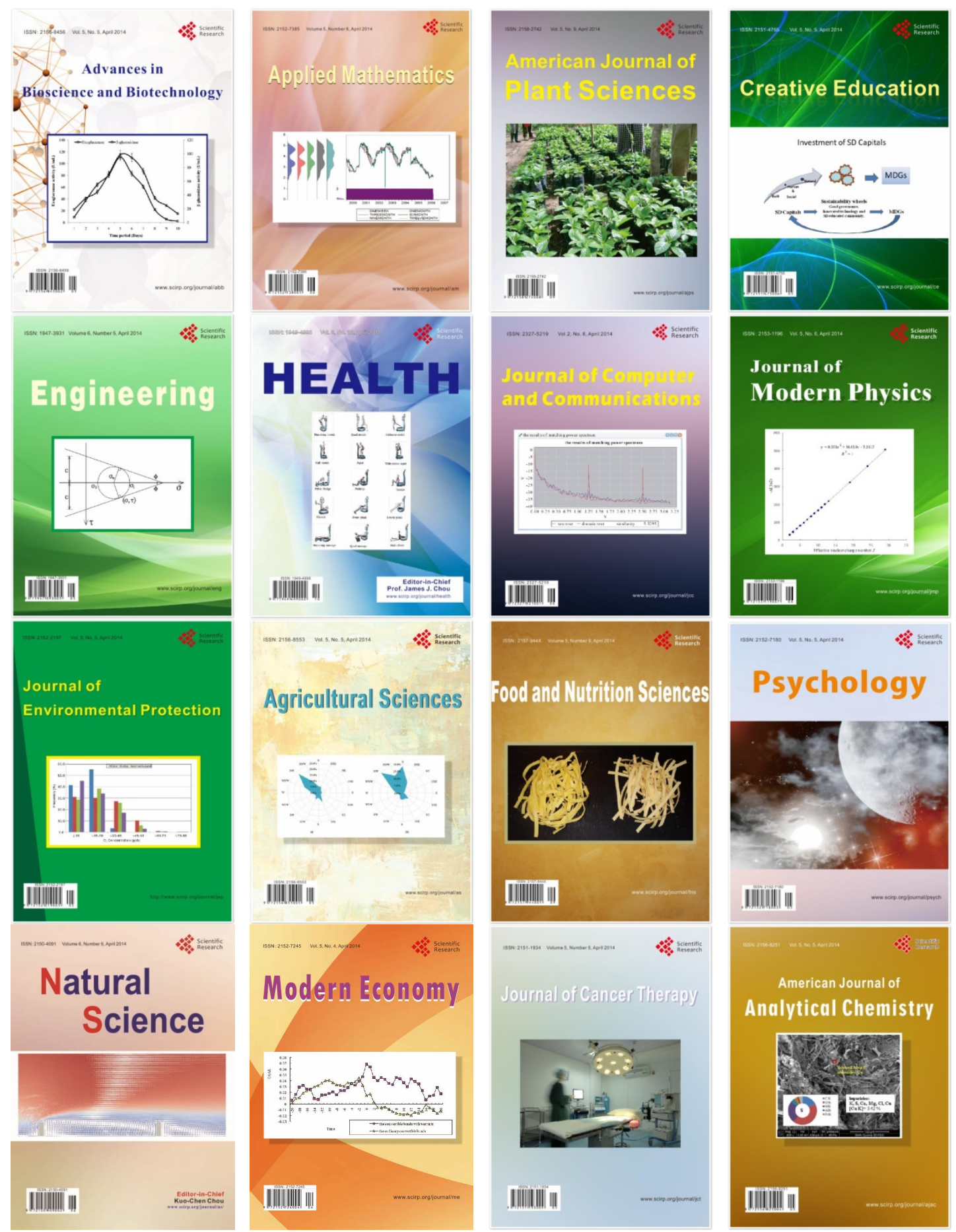